\title{
The Interest Issues of Gifted Children
}

\author{
Ahmet Bildiren ${ }^{1, *}$ \\ ${ }^{1}$ Special Education Department, Adnan Menderes University, Aydın, Turkey \\ *Correspondence: Special Education Department, Adnan Menderes University, Efeler Aydın, Turkey. E-mail: \\ abildiren@adu.edu.tr
}

Received: January 6, 2018

Accepted: January 21, $2018 \quad$ Online Published: January 29, 2018

doi:10.5430/wje.v8n1p17

URL: https://doi.org/10.5430/wje.v8n1p17

\begin{abstract}
Gifted and talented children show differences in many respects compared to normal developing children. It is expected that these differences may also arise in daily life of all these children. In this research, it is aimed to investigate that whether the responses of three wishes questions of the gifted and talented and normal developing children differ or not. The sample of the study consisted of 54 gifted, 28 talented, and 46 normal developing children. Quantitative and qualitative research methods have been used together in the research. The main research question was as follows: "What would you wish if you had three wishes". Received responses were coded and analyzed by chi-square test according to the response types of children with gifted, talented, and normal developing children. As a result of the research, it was determined that the answers given by the gifted, talented, and normal developing children to the three right wishes differed.
\end{abstract}

Keywords: gifted children, talented children, normal developing children, three wishes

\section{Introduction}

Gifted and talented children are different in many aspects (cognitive, affective, social) in comparison with normal developing children (Friedman et al., 2006; Liu, 2009; Liu \& Shi, 2007; Liu, Shi, Zhao, \& Yang, 2008; Zhang et al., 2007). These differences manifest themselves from a very early age. Gifted children can be distinguished by aspects such as their wide areas of interest, questioning attitudes and insistent questions which can be observed from an early age (Clark, 2002; Davis \& Rimm, 2004; Renzulli et al., 2002) and their cognitive characteristics such as curiosity and interaction with their environment are revealed from their babyhood (Porter, 2005).

Greater success, motivation, creativity and social skills are attributed to gifted and talented children during the primary school period (Endepohls-Ulpe, 2005; Garcia-Cepero \& McCoach, 2009). Primary school teachers talk about development indicators that develop more rapidly in these children since such characteristics are more apparent in comparison with normal developing children. Regarding the social and emotional characteristics, primary school teachers emphasize popularity, sincerity and helpfulness as social characteristics of gifted and talented children (Fry, 1984).

Gifted and talented students do not come to the forefront during the school period only as a result of their academic success but they also tend to display greater motivation in comparison with normal developing children (Gottfried \& Gottfried, 1996; Renzulli, 2005) and they tend to put in greater effort in their areas of interest (Csikszentmihalyi, Rathunde, \& Whalen, 1997; Renzulli et al., 2002). It has also been put forth that gifted and talented children are able to organize themselves better with regard to social and emotional aspects in comparison with normal developing children (Liu \& Lien 2005; Neihart, Reis, Robinson, \& Moon, 2002).

In general, there are many empirical findings indicating that gifted and talented children put forth a balanced development. Despite methodological errors, the findings put forth by Terman have been supported by further studies (Masters, 2009; Shurkin, 1992). These studies indicate that gifted children put forth that they are gifted not only by way of attributes related with talent in the broadest sense, but also with socio-emotional and even physical characteristics. A common characteristic of gifted and talented individuals in both scientific and similar opinions is that their cognitive skills are superior in comparison with people of average skills (Porter, 2005; Sternberg, 1990). The experimental studies carried out reveal that gifted and talented students have higher performance levels in comparison with normal developing students in terms of both academic success and self perception (Ataman, 1984; 
Davis \& Connell 1985; Deary, Strand, Smith, \& Fernandes, 2007; Pajares, 1996; Yürük, 2003).

Even though these different characteristics are known by both the families and the teachers or experts, gifted and talented children undergo many different stages in accordance with different identification approaches in order to be identified in a proper manner. For example, neuropsychological tests and neuropsychological tasks (Karakaş \& Doğutepe-Dinçer, 2011) in the neuro-cognitive approach, creative productive activities-experiences in the educational approach (Renzulli, 1999), parental observations (Özbay, 2013), teacher evaluations (Schroth \& Helfer, 2008), peer evaluations (Callahan, Hunsaker, Adams, Moore, \& Bland,1995), and intelligence tests (Burns \& O'leary, 2004; Castellano, 2002; Lohman, Korb, \& Lakin, 2008; Mönks \& Pfluger, 2004; Raven, Raven, \& Court, 1998) are applied for determining gifted and talented children.

Many studies have been carried out for determining the general characteristics of gifted and talented students and for identification these individuals. However, the number of studies on how these students respond to advanced questions that will reveal how these children think and what they want is very limited (Walsh \& Kemp, 2013). Indeed, studies indicate that teachers generally prefer simpler questions in the teaching environment (Dickinson \& Smith, 1994; Hindman, Wasik, \& Erhart, 2012; Zucker, Justice, Piasta, \& Kaderavek, 2010). However, questions which are difficult or which require to think differently may be used to distinguish children with different characteristics.

Will gifted and talented children with such different characteristics respond to different questions different from each other? It is possible that gifted and talented children that put forth different characteristics starting from an early age shall give different responses (Clark, 2002; Davis \& Rimm, 2004; Gross, 1993; Porter, 2005; Renzulli et al., 2002). Even though not all gifted and talented children have the same characteristics, it is expected that gifted and talented children who start talking at an early age and who display a good command of language (Gross, 1993), whose cognitive and advanced cognitive skills (Porter, 2005; Renzulli et al., 2002) are observed at an early age shall think differently and carry out analyses differently in comparison with normal developing children. In addition, specialists who work with gifted and talented children specify the interests and analyses of such children regarding world issues, social, environmental and ethical subjects as an indication of their giftedness and talent (Freeman,1997; Silverman,1994; Winner, 1996). The objective of this study was to analyse the responses of gifted, talented and normal developing children to a three wish question. It is thought that the study results shall contribute to putting forth the characteristics of gifted and talented children. In addition, it is also thought that the responses acquired shall be beneficial as an additional factorthat may be taken into consideration when identification gifted and talented children.

\section{Method}

In this study, qualitative and quantitative research methods have been used together. The use of qualitative and quantitative data to support each other increases the validity and reliability of the study (Creswell, 2013). In parallel, Yıldırım and Şimşek (2005) put forth that using different methods together for acquiring data is important for determining the accuracy and validity of the acquired data as well as the explanations that rely on these data. Method variation is defined as the use of more than one research method and technique for answering the same research question (Yıldırım \& Şimşek, 2005). Therefore, the use of qualitative and quantitative study methods together is explained as method variation (Türnüklü, 2001).

The stage of collecting and coding the data in the study was designed in accordance with the "phenomenology" pattern which is one of the qualitative study patterns. The objective of phenomenological studies is generally to put forth and interpret individual perceptions or perspectives regarding a certain phenomena (Creswell, 2013; Yıldırım \& Şimşek, 2005). Semi-structured interview method was preferred due to the fact that it allows for a more detailed and more in-depth explanation of the opinions of the interviewee in comparison with other data acquisition methods in addition to enabling the researchers to see the issue in question from the perspective of the interviewee (Yıldırım \& Şimşek, 2005). Another advantage of interview forms is that open ended questions that have been prepared beforehand are asked in a systematic order. This provides flexibility to the interview thereby allowing the interviewee to talk more and hence enabling the acquisition of more detailed information (Kuş, 2003).

The quantitative dimension of the study was formed in accordance with the findings acquired from qualitative data. The data prepared in accordance with content analysis were analyzed via chi-square test according to the types responses of the gifted, talented and normal developing children. 


\subsection{Participant (Subject) Characteristics}

Science and Arts Centers have been established by the Ministry of National Education in Turkey for providing special education to gifted and talented children. Students are nominated for Science and Arts Centers by their classroom teachers from private and state schools. The nominated students first enter a group intelligence test followed by WISC-R test for individual examination or a special talent examination (Painting or Music) for the evaluation of special talents. Students who are identified as gifted according to the WISC-R test result (130 and above) or those who are identified as talented according to the special talent test first receive an orientation program in after-school hours followed by a supportive education, program for the realization of individual talents, program for developing special talents and finally project program education (MEB Science and Arts Centers Directive, 2016).

The study group was comprised of 3 groups of children. The first group was comprised of a total of 54 gifted students identifiedas gifted at the İzmir Science and Arts Center according to the WISC-R test with 22 girls (40.04\%) and 32 boys (59.3\%) (Table 1). The age average of gifted children was 10.42, whereas standard deviation was 0.96 . Similarly, the second group was comprised of a total of 28 talented children who were identified as talented at the İzmir Science and Arts Center in the field of art with 14 girls (50\%) and 14 boys (50\%). The age average of talented children was 10.93 , whereas standard deviation was 0.98 . The third group was comprised of a total of 48 normal developing primary school children who put forth a normal performance in the Raven progressive matrices test and who were considered as normal developing according to teacher observations with 16 girls (33.3\%) and 32 boys (66.7\%). The age average of normal developing children was 10.54 , whereas standard deviation was 1.17 .

Table 1. IQ Scores of Gifted Children

\begin{tabular}{lllll}
\hline Gifted children IQ $(\mathrm{n}=54)$ & Min. & Max. & Mean & Std. Deviation \\
\hline Performance IQ & 116 & 145 & 130,20 & 6,69 \\
Verbal IQ & 123 & 153 & 135,85 & 6,37 \\
Total IQ & 130 & 152 & 136,62 & 5,47 \\
\hline
\end{tabular}

\subsection{Instrumentation}

The researcher followed an inductive approach and prepared draft questions for putting forth the creative responses of gifted children while taking into consideration the similar studies as well as interviews with experts in the field. The prepared interview questions were then presented to the opinions of 3 experts in the field. Pre-applications were carried out prior to the study in order to receive feedbacks on whether the questions serve the intended purposes or not. Semi-structured interviews were carried out with 10 gifted and talented children and 10 normal developing children for pre-application purposes on a pre-determined date using the questions thet were rearranged according to expert opinions. It was observed during the pre-applications that the interviews last about 3-4 minutes. It was evaluated during the pre-applications whether the questions are clear and understandable or not and whether they result in questions in the mind of individuals or not; in addition, it was also evaluated whether the participants had difficulties in answering the questions or not. The researcher compared what the participants of the pre-application understood from the questions and what they were expected to understand. It was determined as a result of this comparison that the children who participated in the pre-application understood the questions correctly. In line with this result, the results related with the pre-application were presented once again to expert review after which the questions were given their final state.

At the end of the pre-application, the researcher prepared a form including the question of, "What would you wish if you had three wishes?" along with the responses as 1st wish, 2nd wish and 3rd wish which can be answered as open-ended questions. Afterwards, the question of, "What would you wish if you had three wishes?" was asked by the researcher to gifted, talented and normal developing children individually. The children wrote their response on the form that was previously prepared as 1st wish, 2nd wish and 3rd wish.

\subsection{Sampling Procedures}

The sample group of gifted of the study was selected from the Science and Art Centers which is the only official institution that provides education to gifted children in Turkey. Gifted and talented students in the study group were determined randomly from those enrolled at the İzmir Science and Arts Center. Whereas normal developing children were selected randomly from among students who are enrolled at 3 state schools, who display peer level 
performance according to teacher observations and Raven Standard Progressive Matrice test.

\subsection{Data collection and analysis}

The question form was applied by the researcher individually at the Counseling office of the Science and Art Center. The repeating concepts were determined and grouped after listing the responses to the open ended questions in the form in a table. The grouped data were then analyzed in accordance with content analysis rules (Miles and Huberman, 1994; Silverman, 2000).

Independent coding was carried out by the researcher in addition to a second researcher in order to ensure reliability of the analysis. Afterwards, the formula by Miles and Huberman (1994) in the form of Reliability=[Agreements / (Agreements + Disagreements)] x 100 was used for carrying out a reliability analysis among the coders and a value of 0.90 was calculated. When it is considered that coding reliability should be at least $70 \%$ (Miles and Huberman, 1994), the calculated value indicates that the coding has been carried out in a reliable manner. The data were then re-analyzed in accordance with the agreed codes. The acquired codes were classified according to similarities and agreements as a result of which themese and sub-themes were acquired.

The information acquired as a result of the analysis were interpreted and categorized with an inductive approach (Stake,1995). The acquired data were recorded in a databse. Seven issues were determined according to content analysis (Table 2.). Chi-square test was used for determining whether the response types differ according to being gifted, talented or normal developing.

Table 2. Issues Determined According to Content Analysis

\begin{tabular}{ll}
\hline & Name of Issues \\
\hline 1 & Impossible wishes (immortality, flying, creativity etc.) \\
2 & Materialistic \\
3 & Internal gratification \\
4 & Health, security, happiness \\
5 & Educational \\
6 & Unlimited rights of wishing \\
7 & Universal (World welfare, world peace, invention, social justice) \\
\hline
\end{tabular}

\section{Results}

The results related with the responses of gifted, talented and normal developing children to the three wishes question are given below.

Independent samples chi-square test was used for examining whether there is a relationship between the issue ordering of gifted, talented and normal developing children and their groups. Chi-square value was determined to be statistically significant (chi-square $=49,081$, degrees of freedom 12, $\mathrm{p}<0,001$ ).

When the issues were evaluated according to the groups, issues other than education were determined to have similar values for gifted children (12-19\%). The most distinctive wish in the normal developing group was related with financial (frequency 46, 31.9\%) issues. Internal gratification (frequency 35, 24.3\%) came afterwards. The distinctive wish in the specially gifted group was (frequency 19, 22.6\%) impossible wishes.

The fact that education was reported less in the gifted group is an indication that they do not have any concerns regarding education. Because these children have high academic success and believe that they will be able to sustain this in the future. It can be stated that their ongoing participation to the Science and Art Center reinforces this view. However, the other two groups (Normal developing and talented) expressed more wishes that were relate3d with education in the future. This ratio was quite high especially in the normal developing group (44\%).

When the issues of the gifted group were examined, the impact of close ratios of issues (12-19\%) other than education (4\%) within the group in addition to the wide range of interests along with environmental factors other than the intelligence level can be observed clearly. The awareness levels of gifted children regarding environmental stimuli and their abilities to process these stimuli are quite high. The fact that they have skills and interests in a variety of issues leads us to think that they can be demanding (willing) in different areas. 
Table 3. Chi Square Analysis Results of the Wishes with regard to Being Gifted, Talented and Normal Developing

\begin{tabular}{|c|c|c|c|c|c|}
\hline & & \multicolumn{3}{|l|}{ GROUPS } & \multirow[b]{2}{*}{ Total } \\
\hline & & $\mathrm{G}$ & ND & $\mathrm{T}$ & \\
\hline \multicolumn{6}{|l|}{ İmpossible } \\
\hline & Count & 23 & 20 & 19 & 62 \\
\hline & Expected Count & 25.8 & 22.9 & 13.4 & 62 \\
\hline & $\%$ wihthin Issue & $37.1 \%$ & $32.3 \%$ & $30.6 \%$ & $100 \%$ \\
\hline & $\%$ within Groups & $14.2 \%$ & $13.9 \%$ & $22.6 \%$ & $15.9 \%$ \\
\hline & $\%$ Total & $5.9 \%$ & $5.1 \%$ & $4.9 \%$ & $15.9 \%$ \\
\hline \multicolumn{6}{|l|}{ Material } \\
\hline & Count & 29 & 46 & 9 & 84 \\
\hline & Expected Count & 34.9 & 31 & 18.1 & 84 \\
\hline & $\%$ wihthin Issue & $34.5 \%$ & $54.8 \%$ & $10.7 \%$ & $100 \%$ \\
\hline & $\%$ within Groups & $17.9 \%$ & $31.9 \%$ & $10.7 \%$ & $21.5 \%$ \\
\hline & $\%$ Total & $7.4 \%$ & $11.8 \%$ & $2.3 \%$ & $21.5 \%$ \\
\hline \multicolumn{6}{|l|}{ İnterior } \\
\hline & Count & 32 & 35 & 13 & 80 \\
\hline & Expected Count & 33.2 & $29.5 \%$ & $17.2 \%$ & 80 \\
\hline & $\%$ wihthin Issue & $40 \%$ & $43.8 \%$ & $16.3 \%$ & $100 \%$ \\
\hline & $\%$ within Groups & $19.8 \%$ & $24.3 \%$ & $15.5 \%$ & $20.5 \%$ \\
\hline & $\%$ Total & $8.2 \%$ & $9 \%$ & $3.3 \%$ & $20.5 \%$ \\
\hline \multicolumn{6}{|l|}{ Help, Happy, Security } \\
\hline & Count & 20 & 20 & 13 & 53 \\
\hline & Expected Count & 22 & 19.6 & 11.4 & 53 \\
\hline & \% wihthin Issue & $37.7 \%$ & $37.7 \%$ & $24.5 \%$ & 100 \\
\hline & $\%$ within Groups & $12.3 \%$ & $13.9 \%$ & $15.5 \%$ & $13.6 \%$ \\
\hline & $\%$ Total & $5.1 \%$ & $5.1 \%$ & $3.3 \%$ & $13.6 \%$ \\
\hline \multicolumn{6}{|l|}{ Education } \\
\hline & Count & 8 & 15 & 11 & 34 \\
\hline & Expected Count & 14.1 & 12.6 & 7.3 & 34 \\
\hline & \% wihthin Issue & $23.5 \%$ & $44.1 \%$ & $32.4 \%$ & 100 \\
\hline & $\%$ within Groups & $4.9 \%$ & $10.4 \%$ & $13.1 \%$ & $8.7 \%$ \\
\hline & $\%$ Total & $2.1 \%$ & $3.8 \%$ & $2.8 \%$ & $8.7 \%$ \\
\hline \multicolumn{6}{|l|}{ Eternity } \\
\hline & Count & 29 & 6 & 10 & 45 \\
\hline & Expected Count & 18.7 & 16.6 & 9.7 & 45 \\
\hline & \% wihthin Issue & $6.1 \%$ & $13.3 \%$ & $22.2 \%$ & $100 \%$ \\
\hline & $\%$ within Groups & $17.9 \%$ & $4.2 \%$ & $11.9 \%$ & $11.5 \%$ \\
\hline & $\%$ Total & $7.4 \%$ & $1.5 \%$ & $2.6 \%$ & $11.5 \%$ \\
\hline \multicolumn{6}{|l|}{ Global, Moral } \\
\hline & Count & 21 & 2 & 9 & 32 \\
\hline & Expected Count & 13.3 & 11.8 & 6.9 & 32 \\
\hline & $\%$ wihthin Issue & $65.6 \%$ & $6.3 \%$ & $28.1 \%$ & $100 \%$ \\
\hline & $\%$ within Groups & $13 \%$ & $1.4 \%$ & $10.7 \%$ & $8.2 \%$ \\
\hline & $\%$ Total & $5.4 \%$ & $.5 \%$ & $2.3 \%$ & $8.2 \%$ \\
\hline \multicolumn{6}{|l|}{ Total } \\
\hline & Count & 162 & 144 & 84 & 390 \\
\hline & Expected Count & 162 & 144 & 84 & 390 \\
\hline & $\%$ wihthin Issue & $41.5 \%$ & $36.9 \%$ & $21.5 \%$ & $100 \%$ \\
\hline & $\%$ within Groups & $100 \%$ & $100 \%$ & $100 \%$ & $100 \%$ \\
\hline & $\%$ Total & $41.5 \%$ & $36.9 \%$ & $21.5 \%$ & $100 \%$ \\
\hline
\end{tabular}

When the issues were considered among each other; demands regarding the solution of universal and ethical issues such as hunger, war, global warning, environmental problems along with the issue of helping others were observed 
more frequently in the gifted children group in comparison with the other two groups (65.6\%). Unlimited right of wishing was again determined highest in the gifted children group $(64.4 \%)$.

When the normal developing group is examined, it can be observed that the financial issues are the wishes that had the highest percentage both among themselves $(54.8 \%)$ and the nongifted (31\%) group. It led us to think that the expectation levels of normal developing children were geared more towards raising the quality of life. It can be stated that daily discourses and popular wishes are more dominant in this group. On the contrary, the least expressed wishes were universality (1.4\%) and unlimited right of wishing (4.2\%).

When the Talented group was examined, the most striking result was that impossible wishes have been specified (22.6\%). The fact that these talented students are creative in their respective fields due to both their abilities in painting and music and the education they receive may have led them to make such wishes.

\section{Discussion}

It was determined in this study that compares the responses of gifted, talented and normal developing children to the three wishes question that the responses differed. It is expected that the responses will differ among these groups which differ cognitively, emotionally and socially.

It has been put forth by many studies that gifted and talented children put forth differences in many areas in comparison with normal developing children starting from an early age (Clark, 2002; Manning, 2006; Porter, 2005; Renzulli et al., 2002). Gifted children display superior metacognitive skills starting from early ages. These metacognitive skills surface more when the child is working on a task. Superior memory enables them to learn faster, solve complex problems and remember the tiniest details (Renzulli et.al. 2002; Porter, 2005). In addition, they display a superior command of language in comparison with normal developing children starting from early ages (Clark, 2002; Gross, 1999). It has also been indicated that many gifted children tend to question rules, feel injustice and unfairness at early ages when compared with their normal develoing peers (Clark, 2002; Lovecky, 1997). It is thought that such characteristics that are observed from early ages lead gifted and talented children to respond differently to the questions in comparison with normal developing children. It is especially striking that they demand "unlimited rights of wishing". It can be seen by this response that these children are able to put forth their cognitive and metacognitive skills that they have carried with them since early ages. It cannot be stated that all children who give such different and creative responses are gifted but it is thought that considering the possibility of their giftedness will be beneficial. Contrary to gifted children, normal developing children had more financial wishes. It is expected in our contemporary consumer society and popular culture that financial issues will have priority (Öztürk \& B1kmaz, 2007).

Von Károlyi (2006) carried out a study on $1^{\text {st }} 3^{\text {rd }}$ grade students for determining whether the awareness of gifted children is higher in comparison with average children. Data acquired from the opinions of parents and children as well as intelligence tests put forth that gifted children develop awareness in the social and emotional field at an earlier age in comparison with other children. This social and emotional awareness enables the children to make generalizations beyond their own experiences. These generalitaztions have also affected their spiritual development. According to the results of current studies on the moral development of gifted children, it has been determined that gifted children are different in comparison with normal developing children with regard to physical, emotional and intellectual developments as well as moral development. Majority of the studies carried out in this field determined that the moral interests of children develop at an earlier age and in a more distinctive manner in comparison with their peers depending on their intelligence levels (Roeper \& Silverman, 2009). This moral development brings with it the sense of justice. One of the best known characteristics of gifted children is that they have a strong sense of justice. They can realize inequalities, injustices, double standards thanks to their strong observation skills and ability to think logically and thus question them deeply. Moreover, they feel helplessness and weakness since they see that they do not have the strength to change many things and thus they feel discomfort. They feel anxious regarding all issues such as peace, mortal weapons, their future, the environment and all other problems faced (Roeper \& Silverman, 2009). When the issues are evaluated after acquiring the study results; it was observed that demands for the solution of universal and ethical issues such as hunger, war, global warming, and environmental problems have been reported more in the gifted children group in comparison with the other two groups. It can be stated that the result is due to the early development of social and emotional awareness in gifted children in addition to the fact that they can make generalization as well as their moral developments and sense of justice. The responses of the normal developing children in the study group support this result. Universality was the least expressed wish among the normal developing children. Therefore, the universal wishes of gifted children in comparison with normal developing 
children can be considered as a significant characteristic.

The gifted children in the study group are receiving special education service at the Science and Art Center. It is thought that special education decrease the educational concerns of gifted children. It is thought that if gifted children were to receive education only at their schools, their responses might differ (e.g. unlimited rights of wishing). Because it has been put forth by many studies that when gifted children are included in programs applied for normal developing children, their performances do not increase since they are not faced with applications that force their potentials (Freeman; 1997; Gross, 2002; Sankar-DeLeeuw, 2002; Scruggs, Mastropieri, Cook, \& Escobar 1986; Siegle \& McCoach, 2005). In addition, it has also been determined that gifted children who have not been identified experience problems at school due to emotional and social issues (Akarsu, 2001; Gubbins et.al., 2002; Siegle \& McCoach, 2005). It is also maintained that the placement of small gifted children in classes comprised of average skilled children makes them bored and decreases their motivations (Gross,1999; Neihart \& Olenchak, 2002). When these studies are taken into consideration, it is possible that the wishes related with the education concept of gifted children in the study group are related with the meeting of their education needs.

According to study results, normal developing children made more education related wishes in comparison with gifted and talented children. This result leads us to think that normal developing children have greater concerns related with their career developments. Indeed, theories on career planning consider career development as part of the total development of the individual. Moreover, developmental theorists assume that career development is a process that is ongoing throughout the lives of individuals (Gibson \& Mitchell, 2016). If it is considered that according to Turkey 2016 data there are a total of fifteen million students, the anxieties of normal developing children regarding their education can be considered as a normal result in an environment with increasing competitiveness. Talented children have also made education related wishes even if not as much as normal developing children. Gifted and talented start career planning at earlier ages (Leana-Taşcılar, 2017). It can be stated that these anxieties are due to the opinions of these children who have special talents in fields such as painting and music that they will have difficulties in finding jobs in these fields in the future.

Talented children are creative. They have superior skills in visual and performance arts. They can be realized at early ages. These children can generally be defined as children who have original ideas, who are independent, can take risks, energetic and aware of their creativities (Mastropieri \& Scruggs, 2000). The talented children in the study group have generally responded to the three wishes question in line with these development characteristics. Like the design of a non-existent car, tool of communication, desk or shoe. It can be stated that imagining a car or table that does not exist in our day is related with their skills in developing original ideas. It is considered as beneficial to take into consideration that children who give such creative responses may be talented children.

\section{Conclusion}

In this study, gifted and talented children had different wishes in comparison with normal developing children. When the results of this and previous studies were taken into consideration, it can be stated that taking into consideration the children who give such different responses (unlimited rights of wishing, universal wishes, creative wishes etc.) shall be beneficial for giving the right decision regarding which children are gifted and talented. When the importance of early identification of such children is considered, the importance given by both the parents and the teachers to children who give such responses (Karnes \& Johnson, 1986; Parker \& Nelson 2005; Robinson, 2008; Robinson, Abbott, Berninger, Busse, \& Mukhopadhyay, 1997; Smutny, 1999) shall be of additional support to provide education at an earlier period in line with their skills and interests. However, it should be stated that not all children who give such responses are gifted or talented. But it should be kept in mind that such cognitive or special talents shall result in such different responses to different questions.

\section{References}

Akarsu, F. (2001). Üstün yetenekli çocuklar aileleri ve sorunları. Ankara: Eduser Yayınları.

Ataman, A. G. (1984). Ankara ili resmi şehir ilkokullarındaki üstün yetenekli çocukların fiziksel gelişsim özelliklerinin değerlendirilmesi. Ankara Üniversitesi Eğitim Bilimleri Fakültesi Yayınları.

Burns, T. G., \& O'Leary, S. D. (2004). Wechsler Intelligence Scale for Children-IV: Test review. Applied Neuropsychology, 11(4), 233-236. https://doi.org/10.1207/s15324826an1104_11

Callahan, C. M., Tomlinson, C. A., Hunsaker, S. L., Bland, L. C., \& Moon, T. (1995). Instruments and evaluation designs used in gifted programs (Report No. RM-95132). Storrs, CT: The National Research Center on the 
Gifted and Talented.(ERIC Document Reproduction Service No. ED 429391).

Castellano, J. A. (2002). Renavigating the waters: The identification and assessment of culturally and linguistically diverse students for gifted and talented education. In J. A. Castellano, \& E. I. Diaz (Eds.), Reaching new horizons: Gifted and Talented Education for Culturally and Linguistically Diverse Students (pp. 94-116). Boston, MA: Allyn and Bacon.

Clark, B. (2002). Growing up gifted: Developing the potential of children at home and at school (6th ed.). Upper Saddle River, NJ: Merrill-Prentice Hall.

Creswell, J. W. (2013). Nitel Araştırma Yöntemleri Beş Yaklaşıma Göre Nitel Araştırma ve Araştırma Deseni. Ankara: Siyasal Kitabevi

Csikszentmihalyi, M., Rathunde, K. R., \& Whalen, S. (1997). Talented teenagers: The roots of success and failure. Cambridge, MA: Cambridge University Press.

Davis, G. A., \& Rimm, S. B. (2004). Education of the gifted and talented (5th ed.). Boston, MA: Pearson Education Press.

Davis, H. B., \& Connell, J. P. (1985). The effects of aptitude and achievement status on the self-system. Gifted Child Quarterly, 29, 131-136. https://doi.org/10.1177/001698628502900306

Deary, I. J., Strand, S., Smith, P., \& Fernandes, C. (2007). Intelligence and educational achievement. Intelligence, 35, 13-21. https://doi.org/10.1016/j.intell.2006.02.001

Dickinson, D. K., \& Smith, M. W. (1994). Long-term effects of preschool teachers' book readings on low-income children's vocabulary and story comprehension. Reading Research Quarterly, 29, 105-122. https://doi.org/10.2307/747807

Endepohls-Ulpe, M. (2005). Primary school teachers' criteria for the identification of gifted pupils. High Ability Studies, 16, 219-228. https://doi.org/10.1080/13598130600618140

Freeman, J. (1997). The emotional development of the highly able European. Journal of Psychology in Education, XII, 479-493. https://doi.org/10.1007/BF03172806

Friedman, N. P., Miyake, A., Corley, R. P., Young, S. E., DeFries, J. C., \& Hewitt, J. K. (2006). Not all executive functions are related to intelligence. Psychological Science, 17, 172-179. https://doi.org/10.1111/j.1467-9280.2006.01681.x

Fry, P. S. (1984). Teachers' conceptions of students' intelligence and intelligent functioning: A cross-sectional study of elementary, secondary and tertiary level teachers. International Journal of Psychology, 19, 457-474. https://doi.org/10.1080/00207598408247541

Garcia-Cepero, M. C., \& McCoach, D. B. (2009). Educators' implicit theories of intelligence and beliefs about the identification of gifted students. Universitas Psychologica, 8, 295-310.

Gibson, R. L., \& Mitchell, M. H. (2016) Psikolojik Danışma ve Rehberlik. Ankara: Nobel Yayıncılık.

Gottfried, A. E., \& Gottfried, A. W. (1996). A longitudinal study of academic intrinsic motivation in intellectually gifted children: Childhood through early adolescence. Gifted Child Quarterly, 40, 179-183. https://doi.org/10.1177/001698629604000402

Gross, M. (1993). Exceptionally gifted children. London, England: Routledge. https://doi.org/10.4324/9780203315378

Gross, M. U. M. (1999). Small poppies: Highly gifted children in the early years. Roper Rewiew, 21, 207-14.

Gross, M. U. M. (2002). Gifted children and the gift of friendship. Understanding Our Gifted, 14(3), 27-29.

Gubbins, E. J., Westberg, K. L., Reis, S. M., Dinnocenti, S. T., Tieso, C. L., Muller, L. M., ... \& Burns, D. E. (2002). Implementing a Professional Development Model Using Gifted Education Strategies with all Students. Educational Methods, 2002, 318.

Hindman, A. H., Wasik, B. A., \& Erhart, A. C. (2012). Shared book reading and Head Start preschoolers' vocabulary learning: The role of book-related discussion and curricular connections. Early Education and Development, 23, 451-474. https://doi.org/10.1080/10409289.2010.537250

Karakaş, S., \& Doğutepe-Dinçer, E. (2011). BILLNOT Bataryası El Kitabı: Nöropsikolojik Testlerin Çocuklar için Araştırma ve Geliştirme Çalışmaları: BILLNOT-Çocuk, Ankara. Nobel Tıp Kitabevleri. 
Karnes, M. B., \& Johnson, L. J. (1986). Identification and assessment of gifted/talented handicapped and nonhandicapped children in early childhood. In J. R. Whitmore (Ed.), Intellectual giftedness in vounp children: Recognition and development (pp. 35-54). New York, NY: Haworth Press. https://doi.org/10.1300/J274v18n03_05

Kuş, E. (2003). Nicel-nitel araştırma teknikleri. Ankara: Anı Yayıncılık.

Leana-Taşcılar, Z. M. (2017) Özel yetenekli çocukların psikolojisi. Ankara: Anı Yayıncılık.

Liu, T. (2009). Self-regulation among different intelligent groups of children (Unpublished doctoral thesis). Chinese Academy of Sciences, Beijing, China.

Liu, T., \& Shi, J. (2007). Relationship among working memory, intelligence and creativity of 9 to 11 -years-old children. Chinese Journal of Clinical Psychology, 15, 164-167.

Liu, T., Shi, J., Zhang, Q., Zhao, D., \& Yang, J. (2007). Neural mechanisms of auditory sensory processing in children with high intelligence. NeuroReport, 18, 1571-1575. https://doi.org/10.1097/ WNR.0b013e3282ef7640

Lohman, D., Korb, K., \& Lakin, J. (2008). Identifying academically gifted English-language learners using nonverbal tests: A comparison of the Raven, NNAT, and CogAT. Gifted Child Quarterly, 52, 275-296. https://doi.org/10.1177/0016986208321808

Lovecky, D. (1997). Identity development in gifted children: moral sensitivity. Roeper Review, 20, 90-94. https://doi.org/10.1080/02783199709553862

Manning, S. (2006). Recognizing gifted students: A practical guide for teachers. Kappa Delta Pi Record, 42, 64-68. https://doi.org/10.1080/00228958.2006.10516435

Masters, B. R. (2009). A study of self-actualization of gifted children in public high school programs. Unpublished doctoral dissertation). Holos University, USA.

Mastropieri, M., \& Scruggs, T. (2000). The inclusive classroom: Strategies for effective Instruction Colombus. OH: Merrill.

MEB. (2016). Science and art centers directive. Retrieved April 5, 2017 from: https://orgm.meb.gov.tr/meb_iys_dosyalar/2016_10/07031350_bilsem_yonergesi.pdf

Miles, M. B., \& Huberman, A. M. (1994). Qualitative data analysis (2nd edition). California: Sage Publication.

Mönks, F. J., Pflüger, R., \& Radboud Universiteit Nijmegen. (2005). Gifted education in 21 European countries: Inventory and perspective. Nijmegen: Radboud University Nijmegen.

Neihart, M., \& Olenchak, F. R. (2002). Creatively gifted children. In M. Neihart, S.M. Reis, N.M Robinson, and S.M. Moon (Eds.), The social and emotional development of gifted children (pp. 165-176). Waco, TX: Prufrock Press.

Neihart, M., Reis, S. M., Robinson, N. M., \& Moon, S. M. (2002). The social and emotional development of gifted children: What do we know? Waco, TX: Prufrock Press.

Özbay, Y. (2013). Üstün yetenekli çocuklar ve aileleri. Ankara: Hangar Marka İletişimi ve Reklam Hizmetleri.

Öztürk, D. S. G., \& F. Bıkmaz. (2007). Popüler kültür ve okul: Ankara ve Bolu illerinde ilköğretim öğrencileri üzerinde yapılan bir araştırma. N. Ahioğlu-N. Güney (Yayına Hazırlayanlar). Popüler Kültür ve Çocuk (p. 103-125). Ankara Üniversitesi Çocuk Kültürü Uygulama ve Araştırma Merkezi, Ankara.

Pajares, F. (1992). Teachers' beliefs and educational research: Cleaning up a messy construct. Review of Educational Research, 62, 307-322. https://doi.org/10.2307/1170741

Parker, S. W., \& Nelson, C. A. (2005). The impact of early institutional rearing on the ability to discriminate facial expressions of emotion: An event-related potential study. Child development, 76(1), 54-72. https://doi.org/10.1111/j.1467-8624.2005.00829.x

Porter, L. (2005). Gifted young children (2nd ed.). Berkshire, England: Open University Press.

Raven, J., Raven, J.C., \& Court, H. (1998). Coloured progressive matices (1998 Ed.). USA: Harcourt Assesment.

Renzuli, Joseph S. (2005), The three-ring conception of giftedness, conceptions of giftedness. Cambridge University Pres.

Renzulli, J. S. (1999). Reflections, perceptions, and future directions. Journal for the Education of the Gifted, 23(1), 
125-146. https://doi.org/10.1177/016235329902300109

Renzulli, J. S., Smith, L. H., White, A. J., Callahan, C. M., Hartman, R. K., \& Westberg, K. L. (2002). Scales for rating the behavioral characteristics of superior students (Rev. ed.). Mansfield Center, CT: Creative Learning Press.

Robinson, N. M. (2008). Critical issues and practices in gifted education: What the research says. Early childhood. In J. A. Plucker \& C. M. Callahan (Eds.), (pp. 179-194). Waco, TX: Prufrock Press.

Robinson, N. M., Abbott, R. D., Berninger, V. W., Busse, J. and Mukhopadhyay, S. (1997). Developmental changes in mathematically precocious young children: Longitudinal and gender effects. Gifted Child Quarterly, 41, 145-158. https://doi.org/10.1177/001698629704100404

Roeper, A., \& Silverman, L. K. (2009). Giftedness and moral promise. In Morality, ethics, and gifted minds (pp. 251-264). Springer US. https://doi.org/10.1007/978-0-387-89368-6_19

Sankar-DeLeeuw, N. (2007). Case studies of gifted kindergarten children Part II: The parents and teachers. Roeper Review, 29, 93-99. https://doi.org/10.1080/02783190709554392

Schroth, S. T., \& Helfer, J. A. (2008). Identifying gifted students: Educator beliefs regarding various policies, processes, and procedures. Journal for the Education of the Gifted, 32(2), 155-179. https://doi.org/10.4219/jeg-2008-850

Scruggs, T. E., Mastropieri, M. A., Cook, S. B., \& Escobar, C. (1986). Early intervention for children with conduct disorders: A quantitative synthesis of single-subject research. Behavioral Disorders, 11(4), 260-271.

Shurkin, J. N. (1992). Terman's kids. Boston, MA: Little, Brown.

Siegle, D., \& McCoach, D. B. (2005). Making a difference: Motivating gifted students who are not achieving. Teaching Exceptional Children, 38(1), 22-27. https://doi.org/10.1177/004005990503800104

Silverman, D. (2000). Interpreting qualitative data: Methods for analysing talk, text and interaction. Thousand Oaks, CA: SAGE.

Silverman, L. (1994). The moral sensitivity of gifted children and the evolution of society. Roeper Review, 17, 110-116. https://doi.org/10.1080/02783199409553636

Smutny, J. F. (1999). A special focus on young gifted children. Roeper Review, 21, $172-173$. https://doi.org/10.1080/02783199909553956

Stake, R. E. (1995). The Art of Case Study Research. Thousand Oaks, CA: Sage Publications.

Sternberg, R. J. (1990). Metaphors of mind: Conceptions of the nature of intelligence. New York, NY: Cambridge University Press.

Türnüklü, A. (2001). Eğitim bilim alanında aynı araştırma sorusunu yanıtlamak için farklı araştırma tekniklerinin birlikte kullanılması. Eğitim ve Bilim, 26(120).

Von Károlyi, C. (2006). Issue awareness in young highly gifted children: Do the claims hold up?. Roeper Review, 28(3), 167-174. https://doi.org/10.1080/02783190609554356

Walsh, R. L., \& Kemp, C. R. (2013). Evaluating interventions for young gifted children usingsingle-subject methodology: A preliminary study. Gifted Child Quarterly, 57, 110-120. https://doi.org/10.1177/0016986212466259

Winner, E. (1996). Gifted children (Vol. 1). New York: Basic Books.

Yıldırım, A., \& Şimşek, H. (2005). Qualitative research methods in social sciences. Ankara: Seçkin Publishing.

Yürük, A. (2003). İlköğretim çağındaki üstün yetenekli öğrencilerle normal gelişim gösteren öğrencilerin benlik saygılarının karşılaştırılması. Yüksek Lisans Tezi. H.Ü. Sağlık Bilimleri Enstitüsü, Ankara.

Zhang, Q., Shi, J., Luo, Y., Liu, S., Yang, J., \& Shen, M. (2007). Effect of task complexity on intelligence and neural efficiency in children: An event-related potential study. Developmental Neuroscience, 18, 1599-1602. https://doi.org/10.1097/WNR.0b013e3282f03f22

Zucker, T. A., Justice, L. M., Piasta, S. B., \& Kaderavek, J. N. (2010). Preschool teachers' literal and inferential questions and children's responses during whole-class shared reading. Early Childhood Research Quarterly, 25, 65-83. https://doi.org/10.1016/j.ecresq.2009.07.001 